\title{
ANTIBACTERIAL ACTIVITIES OF NEW AND KNOWN COMPOUNDS PREPARED FROM EUGENOL
}

\author{
I. M. Sudarma ${ }^{1, *}$, M.G. Darmayanti ${ }^{1}$ and Sarkono ${ }^{2}$ \\ ${ }^{1}$ Department of Chemistry, University of Mataram, Mataram-83125, \\ (West Nusa Tenggara) Indonesia \\ ${ }^{2}$ Department of Biology, University of Mataram, Mataram-83125, \\ (West Nusa Tenggara) Indonesia \\ *E-mail : sud_arma@yahoo.co.id
}

ABSTRACT

Eugenol and its new or known derivatives were prepared through varies reactions and screened by in vitro model of antibacterial activities using pathogen bacteria: Eschericia coli, Bacillus cereus, and Staphylococcus aureus. Nearly all compounds showed antibacterial activities. The obtained results demonstrate that eugenol was still significantly more active than its derivatives, with inhibition (14-18) $\mathrm{mm}$, suggesting that this chemical transformation failed to increase antibacterial activities of eugenol. The presence of nitro, cyclic sulfonic ester, N-dimethyl, quinoline, amino, isocyanate, amide and ester moieties has no ability to enhance the antibacterial activities of eugenol.

Keywords: Antibacterial, eugenol, new compounds, synthesis, eugenol derivatives.

(C) RASĀYAN. All rights reserved

\section{INTRODUCTION}

Eugenol is perfumery phenol with IUPAC name 2-methoxy-4-prop-2-enylphenol, a major compound from clove ${ }^{1,2}$. Cloves are the tropical evergreen tree in the family Myrtaceae, Syzygium aromaticum. They are believed indigenous to the Maluku Islands in Indonesia, and are commonly used as a spice in various food preparations ${ }^{3}$. Eugenol shows widely biological activities such as antimicrobial ${ }^{4,5,6}$, antioxidant ${ }^{7,8}$, acaricidal $^{9,10}$, anticancer ${ }^{11}$, anti-imflammatory ${ }^{12}$, etc.

As resistance to antibiotics becomes more common, a greater need for alternative treatments arises. Antibiotics have saved millions of lives against infection by bacteria. Irrational use of an antibiotic can cause dangerous effects against a human being. One, in particular, is the big problem of bacteria resistance against present antibiotic ${ }^{13}$. Antibiotic resistance can cause serious disease and is a major public health problem. Antibiotics are grossly abused in developing countries, especially in Africa and Asia for example, purchase without prescription in local pharmacies and drug stores. One alternative to solve this problem is by designing and synthesizing new or novel bioactive compounds as the next generation antibiotics which can replace the present resistance antibiotic. Design and synthesis of new and novel antibiotic can use natural products as source material. Readily accessed natural products, in particular eugenol which is easily isolated from the dried leaves of clove and could be used as a starting material. In continuation of our research on natural products particularly eugenol, chemical transformation and an antibacterial assay of eugenol and its derivatives were reported.

\section{Materials and Methods}

\section{EXPERIMENTAL}

Eugenol (A) and its analogs (B-J) obtained from the chemical transformation of eugenol (Scheme-1). The"Laboratórium Microbiology Fakultas Peternakan Universitas Mataram Indonesia"supplied the bacterial S. aureus, B. cereus, and E. coli. Suitable solvent was used for the dissolution of the pure compounds and obtained from Sigma.

Rasayan J. Chem., 12(2), 761-764(2019)

http://dx.doi.org/10.31788/RJC.2019.1225115

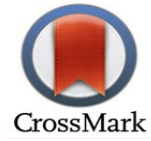




\section{General Procedure}

Preparation of test bacteria was adopted from Artur Smânia $\mathrm{Jr}^{13}$. The antibacterial screening of eugenol (A) and its analogs (B-J) was assessed against three bacteria species: S. aureus, B. cereus, and E. coli maintained at $20^{\circ} \mathrm{C}$ in Brain Heart Infusion (BHI); of each stock-culture $(300 \mathrm{~mL})$ were added to $3 \mathrm{~mL}$ of BHI broth. Cultures were kept overnight $(24 \mathrm{~h})$ at $36^{\circ} \mathrm{C} \pm 1{ }^{\circ} \mathrm{C}$ and after $8 \mathrm{~h}$ of incubation the purity of cultures was checked. Suspension of bacteria was diluted with sterile physiological solution, for turbidity tests, (turbidity standard 0.5), and diluted with BHI broth to a density $10^{9} \mathrm{UFC} / \mathrm{mL}$ (McFarland standard 3). ${ }^{14,15}$

Inoculum of bacterial was spread on a sterile Petri dish agar using sterile cotton swab. Sample (50 $\mathrm{mg}$ ) was dissolved in dimethylsulfoxide (DMSO) $(10 \mathrm{~mL})$ yielded concentrations of $5 \mathrm{mg} / \mathrm{mL}$ for pure substances. Pure compounds $(50 \mu \mathrm{L})$ were added to each of well according to its code and incubated at $36^{\circ} \mathrm{C} \pm 1^{\circ} \mathrm{Cfor} 24 \mathrm{~h}$, under aerobic conditions. Zone of inhibition was observed. Zone of Inhibition (ZOI) was measured in $\mathrm{mm}$. Two replications (R1 and $\mathrm{R} 2)$ were performed in this test.

\section{RESULTS AND DISCUSSION}

New and novel compounds are synthesized without any biological activities tests are not valuable. Antibiotic screening is a simple method to determine the biological activities of new or known compounds. Ten compounds were screened against three bacteria species namely eugenol (A) and nitroeugenol (B) both are known compounds and eight new compounds (C-J) which were easily synthesized from eugenol (A) $(\text { Scheme-1) })^{16}$.<smiles>C=CCc1ccc(O)c(OC)c1</smiles><smiles>C=CCc1cc(OC)c(O)c(N(C)C)c1</smiles><smiles>C=CCc1cc(N)c(OC(C)=O)c(OC)c1</smiles>

B

Reaction Conditions:

Scheme-1: Synthesis of Eugenol Derivatives (B-J).

1. $\mathrm{ClSO}_{3} \mathrm{H}$, Dichloromethane, reflux, 15 ,

2. $\mathrm{NH}_{4} \mathrm{NO}_{3} / \mathrm{KHSO}_{4}, \mathrm{CH}_{3} \mathrm{CN}$, rt, $0.5 \mathrm{~h}$, reflux, $5 \mathrm{~h}$ 
3. $\mathrm{CH}_{2} \mathrm{O}, \mathrm{HCOOH} / \mathrm{Zn}, \mathrm{CH}_{3} \mathrm{CH}_{2} \mathrm{OH}, 65^{\circ} \mathrm{C}, 4.5 \mathrm{~h}$

4. $\mathrm{CH}_{3} \mathrm{CH}_{2} \mathrm{O}, \mathrm{HCl} / \mathrm{Fe}, \mathrm{CH}_{3} \mathrm{CH}_{2} \mathrm{OH}: \mathrm{H}_{2} \mathrm{O}, 65^{\circ} \mathrm{C}, 4.5 \mathrm{~h}$

5. $\mathrm{Sn} / \mathrm{HCl}, \mathrm{CH}_{3} \mathrm{CH}_{2} \mathrm{OH}$, reflux

6. $\mathrm{CS}_{2}$, THF, rt, $24 \mathrm{~h}$

7. $\mathrm{ClCOCH}_{3}$, Dichloromethane, $0-5^{\circ} \mathrm{C} 15^{\prime}, \mathrm{rt}, 1 \mathrm{~h}$

Eugenol (A) as control and its synthetic analogs (B-J) were tested in vitro against 3 pathogen bacteria species.e. S. aureus, B. cereus, and E. coli. Zone of inhibition (ZOI) of these ten compounds against these bacteria was presented in Table-1.

Table-1: Average of the Zone of Inhibitions (mm) of Eugenol (A) and Its Derivatives (B-J) against E. coli, B. cereus, and S. aureus

\begin{tabular}{c|c|c|c}
\hline \multirow{2}{*}{$\begin{array}{c}\text { Eugenol and its } \\
\text { derivatives }\end{array}$} & \multicolumn{3}{|c}{ Zone of inhibitions (mm) } \\
\cline { 2 - 4 } & E. coli & B. cereus & S. aureus \\
\hline $\mathrm{A}$ & 15.5 & $(\mathrm{R} 1+\mathrm{R} 2) / 2$ & $(\mathrm{R} 1+\mathrm{R} 2) / 2$ \\
\hline $\mathrm{B}$ & 11.5 & 17.5 & 16.5 \\
\hline $\mathrm{C}$ & 9.5 & 10.5 & 11.5 \\
\hline $\mathrm{D}$ & 8 & 9.5 & 10 \\
\hline $\mathrm{E}$ & 7.5 & 4.5 & 8.5 \\
\hline $\mathrm{F}$ & 4 & 3.5 & 9.5 \\
\hline $\mathrm{G}$ & 7.5 & 3 & 4 \\
\hline $\mathrm{H}$ & 4 & 3.5 & 3.5 \\
\hline $\mathrm{I}$ & 4.5 & 4 & 3.5 \\
\hline $\mathrm{J}$ & 4 & 9.5 & 9.5 \\
\hline
\end{tabular}

Table 1showed that eugenol (A), and derivatives (B-J) exhibited an inhibitory effect on three bacteria examined, with diameter inhibitory value $(3.5-17.5) \mathrm{mm}$. Eugenol (A) was significantly more active than its derivatives with inhibition (15.5-17.5) $\mathrm{mm}$ and its derivatives have range inhibition (4-11.5) $\mathrm{mm}$, suggesting that the presence of nitro $(\mathbf{B})$, cyclic sulfonic ester $(\mathbf{C}), \mathrm{N}$-dimethyl $(\mathbf{D})$, quinoline $(\mathbf{E})$, amino $(\mathbf{F})$, isocyanate $(\mathbf{G}, \mathbf{H})$, amide and ester $(\mathbf{I}, \mathbf{J})$ has no ability to enhance the antibacterial activities of eugenol.

\section{CONCLUSION}

Eugenol (A) and its analogs (B-J) showed antibacterial activities against Eschericia coli, Bacillus cereus, and Staphylococcus aureus. Eugenol (A) performed the highest zone of inhibitions compare to its derivatives (B-J). These preliminary results were a starting point for further pharmaceutical investigations.

\section{ACKNOWLEDGMENT}

This research was supported by the Ministries of Research, Technology, and Higher Education Republic of Indonesia through "Penelitian Berbasis Kompetensi" Research Grant 2018 for financial support.

\section{REFERENCES}

1. Eugenol, Wikipedia, https://en.wikipedia.org/wiki/Eugenol [accessed Dec, 18, 2017].

2. D.V. Prabhu and Chetana Rana, Rasayan J. Chem., 8 (4), 459 (2015

3. Clove. Wikipedia, https://en.wikipedia.org/wiki/Clove [accessed Dec, 18, 2017].

4. S. M. Ali, A. Khan, I. Ahmed, M. Musaddiq, K.S. Ahmed, H. Polasa, L.V. Rao, C.M. Habibullah, L. A. Sechi, N. Ahmed, Ann. Clin. Microbiol. Antimicrob., 4, 20 (2005), DOI:10.1186/1476-0711-4-20 
RASĀYAN J. Chem.

Vol. 12 | No. 2 |761 - 764| April - June | 2019

5. A. Marchese, R. Barbieri, E. Coppo, I. E. Orhan, M. Daglia, S.F. Nabavi, M. Izadi, M. Abdollahi, S.M. Nabavi, M. Ajami, Methods Mol. Biol..,610, 165(2010), DOI: 10.1080/1040841X.2017.1295225

6. S. A. Burt, R. D. Reinders, Lett. Appl. Microbiol., 36(3), 162(2003)

7. E. Nagababu , J. M. Rifkind, S. Boindala, L. Nakka, Methods Mol Biol. 610, 165 (2010), DOI: $10.1007 / 978-1-60327-029-8 \_10$

8. M.B. Hossain, N.P. Brunton, C. Barry-Ryan, A.B. Martin-Diana, and M. Wilkinson, Rasayan J. Chem., 1(4), 751 (2008)

9. C. Pasay, K. Mounsey, G. Stevenson, R. Davis, L. Arlian, M. Morgan, D. Vyszenski-Moher, K. Andrews, J. McCarthy, Plos. One, Tenth anniversary. Published: August 11, (2010), DOI: 10.1371/journal.pone.0012079

10. S. I. Kim, J. H. Yi, J. H. Tak, Y. J. Ahn., Vet Parasitol. 120(4), 297(2004), DOI:10.1016/j.vetpar.2003.12.016

11. A. Carrasco, C. Espinoza, V. Cardile, C. Gallardo, W Cardona, L. Lombardo, M. Catalán, F. Cuellar, A. Russo (2008), J. Braz. Chem. Soc. 19(3) (2008), DOI: 10.1590/S0103-50532008000300024

12. K. Thakur and K.S. Pitre, Rasayan J. Chem., 2 (2), 472 (200)

13. D. Criswell. (2004), The "Evolution" of Antibiotic Resistane, http://www.icr.org/article/evolutionantibiotic-resistance/ [accessed Dec 20, 2017].

14. C. Valgas, S. Machado de Souza, E. Smânia, A. Smânia, Braz. J. Microbiol., 38(2) (2007), DOI: $10.1590 /$ S1517-83822007000200034

15. McFarland Standards. Wikipedia, https://en.wikipedia.org/wiki/McFarland_standards [accessed Dec, 20, 2017].

16. Supporting Information accompanies this paper on https://www.scopus.com/authid/detail.uri?authorId=55990230100, http://orcid.org/0000-0002-3735-

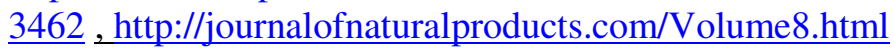

[RJC-5115/2018] 